\title{
Nail changes secondary to hand-foot-mouth disease
}

\author{
Nebahat Demet Akpolat ${ }^{1}$, Nezih Karaca ${ }^{2}$ \\ ${ }^{1}$ Department of Dermatology, Beykoz State Hospital and ${ }^{2}$ Clinic of Nisantası Sculpture, Istanbul, Turkey. \\ E-mail: drdemetakpolat@gmail.com \\ Received: 20 May 2016, Revised: 11 July 2016, Accepted: 26 July 2016
}

\begin{abstract}
SUMMARY: Akpolat ND, Karaca N. Nail changes secondary to hand-footmouth disease. Turk J Pediatr 2016; 58: 287-290.

Hand-foot-mouth disease (HFMD) is a viral disease that is characterized by palmoplantar vesicular eruption and erosive stomatitis. Beau's line and onychomadesis can be observed as late findings following HFMD due to arrest in nail matrix. We aimed to draw attention to HMFD and nail changes, which have been seen more frequently.
\end{abstract}

Demographic characteristics and nail findings of 15 children, who were diagnosed with HFMD in the dermatology clinic of Beykoz State Hospital between August 2015-October 2015 were evaluated.

Mean age of the patients was 5.13 years (1-13 years), $66.6 \%$ were boys $(n=10)$, and $33.4 \%$ were girls $(n=5) ; 53.3 \%$ were diagnosed in August $(n=8)$. Dermatologic examinations revealed palmar and plantar vesicular eruptions in all cases, additionally one patient had vesicular eruptions also on hip, legs, and arms. Erosive stomatitis was present in oral mucosa of $60 \%$ of patients $(n=9)$. Nail findings were determined after a mean of 4.06 weeks following HFMD. Onychomadesis and Beau's line were present in $66.6 \%(n=10)$ and $33.4 \%$ of the patients, respectively.

Hand-foot-mouth disease is a viral infection of childhood, which may be seen as isolated cases or epidemics, and characterized with palmoplantar vesicular eruption and erosive stomatitis. Being aware that Beau's line and onychomadesis can be seen as late findings of HFMD and should relieve without treatment, will prevent unnecessary diagnostic and invasive interventions.

Key words: hand-foot-mouth disease, onychomadesis, Beau's line.

Hand-foot-mouth disease is a frequently seen infection of childhood, which caused by picornavirus family (Coxsackie virus, Enterovirus, Echovirus), and characterized with palmoplantar vesicular eruption and erosive stomatitis. ${ }^{1}$ The most frequent etiological agents in either isolated cases or epidemics are Coxsackie virus A16 and Enterovirus 71 $(\mathrm{EV} 71)^{2}$. Late term nail dystrophies in this disease, which do not necessitate treatment, are onychomadesis and horizontal ducting (Beau's line).

In this study, demographic characteristics and nail findings of children who were diagnosed with HFMD were reviewed in order to raise awareness about the nail changes that might be seen and spontaneously relieved without treatment during the course of this disease.

\section{Material and Methods}

Fifteen children, who were diagnosed with hand-foot-mouth disease at the dermatology clinic of Beykoz State Hospital between August and October 2015 were evaluated regarding age, sex, lesion distribution, oral mucosa involvement, time to progression of nail findings, and nail changes (Table I). Patients were divided into two groups according to their ages $\leq 5$ (Group 1) and >5 (Group 2).

Numerical data of the study were presented as mean and standard deviation, and categorical data were presented as frequency and percent. Categorical variables were compared by using Chi-square test. Statistical significance level (p) was determined as 0.05 and $p<0.05$ was regarded as statistically significant. Statistical analyses were performed in SPSS 15.0 software. 


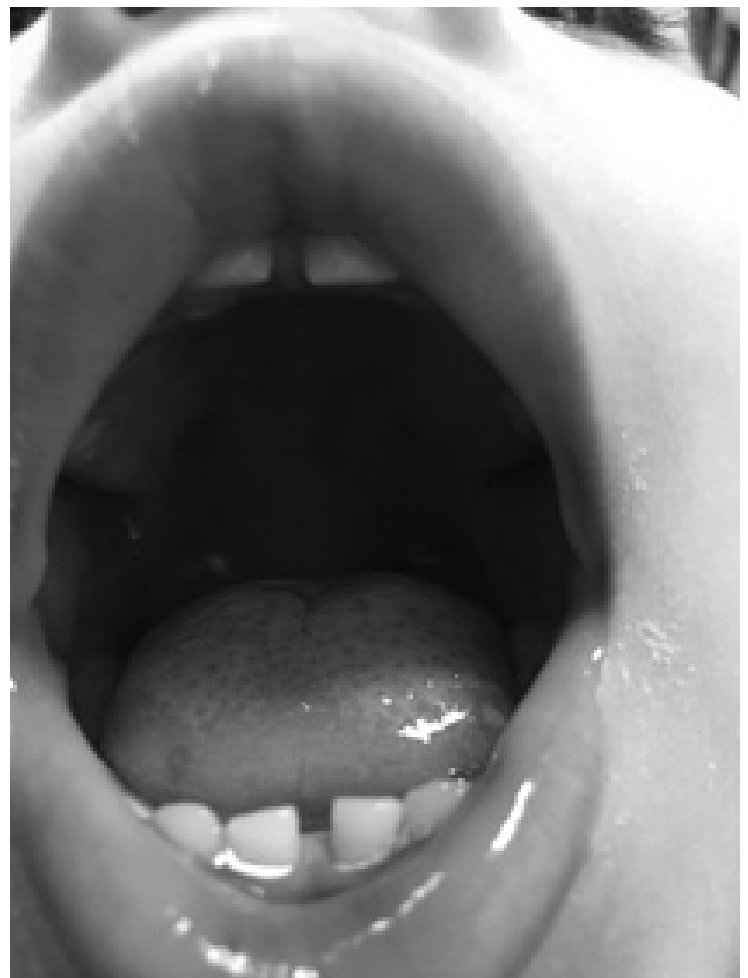

Fig. 1. Erosive mucosal stomatitis
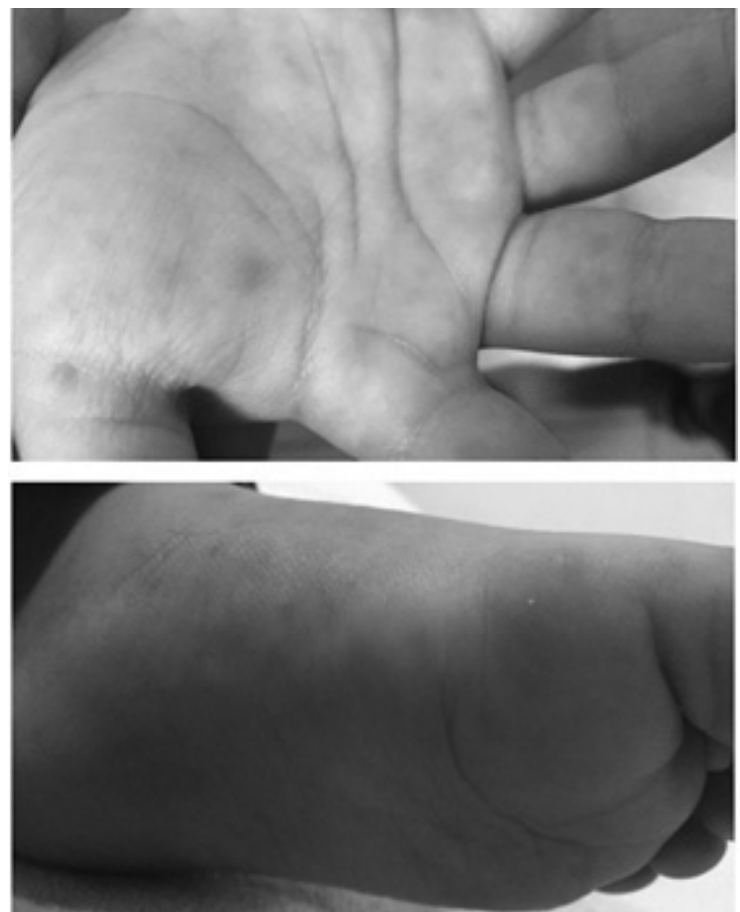

Fig. 2. Vesicular erupsion located on the palmoplantar area

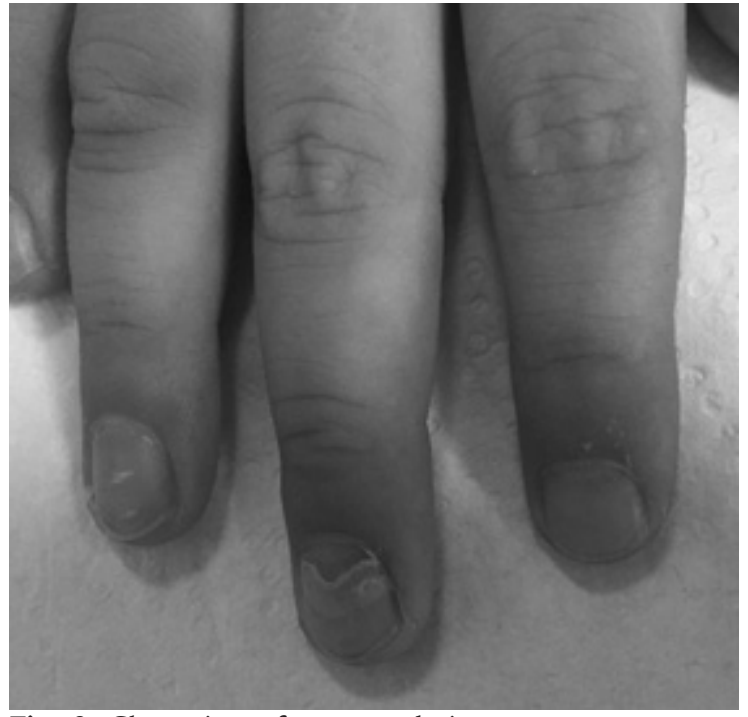

Fig. 3. Close view of onycomadesis

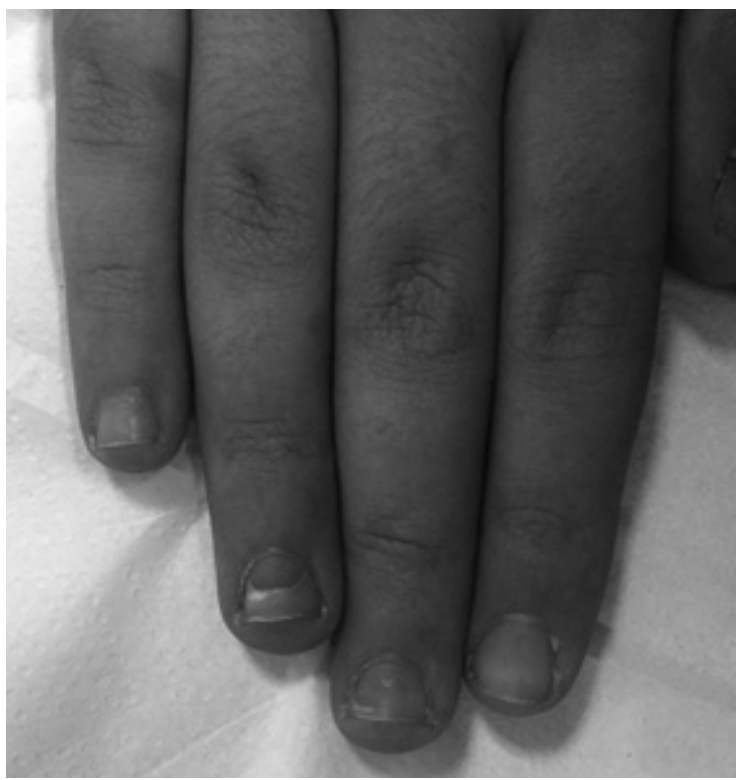

Fig. 4. Close view of Beau's lines 


\section{Results}

Mean age of the patients was 5.1 years (1-13 years) and $66.6 \%(n=10)$ were younger than 5 years. When grouped according to age, $66.6 \%$ $(n=10)$ were group 1 , and $33.4 \%(n=5)$ were group 2. Sex distribution of children was $66.6 \%$ $(n=10)$ boy, and $33.4 \%(n=5)$ girl; $53.3 \%$ $(n=8)$ of children were seen in August.

Dermatologic examinations revealed vesicular eruptions in palmar and plantar regions in all cases (Fig. 1), and additionally, one patient had vesicular eruptions also on hips, legs and arms. Erosive stomatitis were found on oral mucosa of $60 \%(n=9)$ of patients (Table I; Fig. 2). Group comparisons revealed erosive stomatitis was present in $80 \%(n=8)$ of patients in Group 1 , and $20 \%(n=1)$ of patients in Group 2 (Table II). Rate of oral mucosa lesions were significantly higher in Group 1 (5 years-old and younger) (Chi-square, $\mathrm{p}<0.05$ ).

Nail findings were recorded after a mean of 4.06 weeks following HFMD. Nail findings were seen after 4.2 weeks in Group 1, and after 3.8 weeks in Group 2. Nail changes were seen in a shorter period in patients over 5 years of age (Group 2 ), but there was no significant difference (Chisquare, $\mathrm{p}>0.05)$. Onychomadesis was present in $66.6 \%$ of the patients (Fig. 3), and Beau's line was present in $33.4 \%$ of the cases (Fig. 4) (Table I). Onychomadesis was present in all cases in Group 2; but in Group 1, 50\% of the cases had onychomadesis, and $50 \%$ had Beau's line (Table II). Although all cases over 5 years of age had onychomadesis, there was no significant relationship between age and nail changes (Chi-square, $\mathrm{p}>0.05$ ).

\section{Discussion}

Hand-foot-mouth disease is a viral infection, which transmits by fecal-oral or respiratory ways, especially affects children under 5 years-of-age, and characterized by vesicular palmoplantar eruption and erosive stomatitis. ${ }^{1,3}$

Table I. Demographic Characteristic and Nail Changes

\begin{tabular}{lccccccc}
\hline Case & $\begin{array}{c}\text { Age } \\
\text { (year)/Sex }\end{array}$ & Initiation & $\begin{array}{c}\text { Cutaneous } \\
\text { distribution }\end{array}$ & Oral lesion & Time passed & Onychomadesis & $\begin{array}{c}\text { Beau's } \\
\text { line }\end{array}$ \\
\hline 1 & $2 / \mathrm{M}$ & August & Palmoplantar & + & 4 weeks & - & + \\
2 & $4 / \mathrm{M}$ & October & Palmoplantar & + & 3 weeks & - & + \\
3 & $10 / \mathrm{M}$ & August & Palmoplantar & - & 4 weeks & + & - \\
4 & $4 / \mathrm{K}$ & September & Palmoplantar & + & 7 weeks & + & - \\
5 & $1 / \mathrm{M}$ & August & Palmoplantar & + & 4 weeks & - & + \\
6 & $2 / \mathrm{M}$ & October & Palmoplantar & + & 3 weeks & - & + \\
7 & $9 / \mathrm{K}$ & August & Palmoplantar & + & 4 weeks & + & - \\
8 & $2 / \mathrm{K}$ & August & Palmoplantar & - & 6 weeks & - & + \\
9 & $4 / \mathrm{M}$ & October & Palmoplantar & + & 3 weeks & + & - \\
10 & $13 / \mathrm{M}$ & September & Palmoplantar & - & 4 weeks & + & - \\
11 & $7 / \mathrm{M}$ & August & Palmoplantar & - & 3 weeks & + & - \\
12 & $8 / \mathrm{K}$ & September & Palmoplantar & - & 4 weeks & + & - \\
13 & $5 / \mathrm{K}$ & August & Palmoplantar & + & 5 weeks & + & - \\
14 & $4 / \mathrm{M}$ & August & Palmoplantar & + & 4 weeks & + & - \\
15 & $2 / \mathrm{M}$ & October & Palmoplantar & - & 3 weeks & + & - \\
\hline
\end{tabular}

Table II. Nail Findings and Erosive Stomatitis According to Age Groups

\begin{tabular}{lccc}
\hline & Onychomadesis & Beau's line & Erosive stomatitis \\
& $\mathrm{N} \%$ & $\mathrm{~N} \%$ & $\mathrm{~N} \%$ \\
\hline Group 1 $(\leq 5$ years, $\mathrm{n}=10)$ & 550 & 550 & 880 \\
Group 2 $(>5$ years, $\mathrm{n}=5)$ & 5100 & 00 & 120 \\
\hline
\end{tabular}


In our study, mean ages of the cases was between 1-13 years (mean 5.1 years), and $66.6 \%(\mathrm{n}=10)$ were under 5 years. A previous study by Uğraş et al. ${ }^{3}$ reported their patients' ages as 9 months-15 years and most of them were under 5 years $(87.4 \%)$, such as in our study.

Warm climate and global warming increases the incidence of enterovirus infections. ${ }^{4}$ Most of our cases (53.3\%) were admitted in August, in conjunction with the literature data. Clinical attack rates are higher in early childhood, and more frequent in lower socioeconomic groups. ${ }^{5}$

Hand-foot-mouth disease generally starts with oral lesions after 4-6 days of incubation period. Aphthous lesions may progress in any localization on oral mucosa with changing numbers from a few to 10 . Generally, they are small and asymptomatic lesions. ${ }^{1}$ In our study, $60 \%$ of cases $(n=9)$ had erosive stomatitis on oral mucosa, and this rate was higher in patients under 5 years $(80 \%)$. Cutaneous lesions are generally seen in $2 / 3$ of patients after 24 hours of enanthem. They initiate as red macule and papules of 3-7 $\mathrm{mm}$, and they rapidly change to vesicles surrounded by erythematous halo. Vesicles generally localized in palmoplantar region, but sometimes may extend to face, gluteal field, or extremities. ${ }^{1}$ In our study, all cases had palmoplantar vesicular eruption, and one case also had vesicular eruption on hips and extremities. Likewise, Shin et $\mathrm{al}^{6}$. also reported the most frequent site of involvement as palmoplantar region $(61.4 \%, 8 / 13)$ and secondly as oral involvement $(53.84 \%, 7 / 13)$.

Onychomadesis is described as spontaneous and complete splitting of proximal nail plate from nail bed and matrix, after temporary arrest of nail development. ${ }^{8}$ Likewise, Beau's line is a horizontal sulcus that develops after temporary arrest of nail growth. If these changes affect a higher number or all of nails, then they might be related with diseases and conditions such as bullous dermatitis, acrodermatitis enteropatica, Kawasaki disease, measles, hand-foot-mouth disease, Stevens-Johnson syndrome, fever, and drugs. ${ }^{8}$ Mechanism of development is not clear, but might be related with the close proximity of infection with nail, and affection of nail bed by inflammation, or long-term arrest of nail growth by a severe hand-foot-mouth disease to develop onychomadesis. ${ }^{9}$ In our study, we found that nail findings develop 4.06 weeks after HFMD; which is 4.2 weeks in Group 1, and 3.8 weeks in Group 2. Shin et $\mathrm{al}^{6}$. reported the interval to progression of nail changes as 5.92 weeks. In our study onychomadesis and Beau's line were found in $66.6 \%(n=10)$ and $33.4 \%$ of cases, respectively. Likewise, Kim et al ${ }^{7}$. reported onychomadesis and Beau's line were found in $75 \%(n=3)$ and $25 \%(n=1)$ in their cases, respectively.

In conclusion, incidence of HFMD has been increasing in recent years and frequently seen in children younger than 5 years of age. Although it is a benign condition, families are concerned with the late-term nail changes. Being aware of these nail changes and that they do not necessitate any treatment and should relieve spontaneously will prevent unnecessary treatments and invasive interventions.

\section{REFERENCES}

1. Habif PT. Hand-foot-mouth disease. In: Exantems and drug eruptions. Clinical Dermatology: A color guide to diagnosis and therapy (6th ed). Hanover: Habif and Thomas; 2016: 538-539.

2. Bucak İH, Almıș H, Turgut M. El, ayak, ağız hastalığ ve tırnak bulguları. Editöre Mektup. Turkiye Klinikleri J Pediatr 2015; 24: 123-124.

3. Uğraş $M$, Kücük Ö, Biçer $S$ ve ark. İki yıllık periyot içinde el-ayak-ağız hastalığı olan çocukların değerlendirilmesi. Kartal Eğitim ve Araştırma Hastanesi Tip Dergisi 2014; 25: 34-38.

4. Urashima M, Shindo N, Okabe N. Seasonal models of herpangina and hand-foot-mouth disease to simulate annual fluctuations in urban warming in Tokyo. Jpn J Infect Dis 2003; 56: 48-53.

5. Macini AJ, Shani-Adir A. Enteroviruses. In: Infections, infestations and bites. Bolognia: Dermatology (2nd ed) Vol. 1. Spain: Anthony and Ayelet; 2008: 1220-1221.

6. Shin JY, Cho BK, Park HJ. A clinical study of nail changes occuring secondary to hand-foot-mouth disease: onychmadesis and Beau's line. Ann Dermatol 2014; 26: 280-283.

7. Kim EJ, Park HS, Yoon HS, Cho S. Four cases of onychomadesis after hand-foot-mouth disease. Ann Dermatol 2014; 26: 777-778.

8. Sotiriadis DK. Hair and nail disorders of childhood. Expert Rev Dermatol 2008; 3: 677-690.

9. Haneke E. Onychomadesis and hand, foot and mouth disease--is there a connection? Euro Surveill 2010; 15: pii $=19664$. 